\title{
Study on heterogeneous reaction between tar and ash from waste biomass pyrolysis and gasification
}

\author{
Q. Wang, T. Endo, P. Apar, L. Gui, Q. Chen, N. Mitsumura, \\ Q. Qian, H. Niida, S. Animesh \& K. Sekiguchi \\ Department of Environmental Science and Technology, \\ Graduate School of Science and Engineering, Saitama University, Japan
}

\begin{abstract}
Fossil energy resources that are available in the world are exhaustible. Therefore, the renewable biomass resource has attracted a lot of attention as the future energy resource. In addition, it is an advantage that the biomass grows while absorbing $\mathrm{CO}_{2}$, contributing to the prevention of global warming. Biomass utilization technologies are classified as pyrolysis and gasification, fermentation, and combustion. Fuel gases and synthesis gases produced by the pyrolysis and gasification is used as power generation, heating, chemical products, etc. However, pyrolysis and gasification processes also generated condensable organic compounds, so-called "tar". Most tar contents are present as the gases at high temperature. However, when the temperature is cooled down lower than their boiling point, causing a black oily liquid lead to the equipment failure, the appropriate processing is required. As the processing method, using the catalytic tar decomposition has been widely studied.

In the present study, we have carried out the thermal decomposition of cellulose, in the experimental apparatus modeling a fluidized bed gasifier. The thermal decomposition of cellulose, tar and gas is generated, tar is collected and cooled, and the gases were measured by a gas-chromatograph with a flame ionization detector (GC-FID) and with a thermal conductivity detector (GCTCD). Then, $\mathrm{K}$ and $\mathrm{Ca}$ are selected as the catalysts of alkali metals and alkaline earth metals contained in the waste biomass. They are present in the state of oxide or carbonate during pyrolysis and gasification. We conducted a similar experiment. The amount of condensable products and heavy tar were decreased by installing $\mathrm{K}_{2} \mathrm{CO}_{3}$ and $\mathrm{Ca}(\mathrm{OH})_{2}$. Additionally, they brought further gas
\end{abstract}


production. It can be concluded that alkali metal compound $\left(\mathrm{K}_{2} \mathrm{CO}_{3}\right)$ and alkaline earth compound $(\mathrm{CaO})$ have a catalytic effect to decompose tar contents, to enhance gaseous production.

Keywords: biomass, pyrolysis, heterogeneous reaction, alkali metal, alkaline earth metal, tar decomposition.

\section{Introduction}

Focusing on developing countries, it is expected that the amount of energy consumption is increased in the world. Oil, coal, and natural gas are exhaustible resources used to fulfill the energy requirement in the world. Large amounts of carbon dioxide emissions occur when these former energy sources are present, promoting global warming. Recently, attention has been attracted by the biomass of renewable energy resource. Features, carbon positive, resources are present all over the world, etc. Thermal decomposition and gasification are methods which are used to convert biomass to energy. The gas obtained by the thermal decomposition and gasification mainly composed of $\mathrm{H}_{2}$ and $\mathrm{CO}$. These synthesis ammonia, liquid fuel, methanol, and chemical products and a variety of derivative products are manufactured [1]. However, amount of a condensable organic compound called tar is produced during thermal decomposition and gasification. Tar clogs the pipe of gasifier and break turbine. Both mechanical methods and thermal cracking have been proposed to remove tar.

Mechanical methods do not allow energy recovering from tar which are just removed from gaseous products, while thermal cracking requires high temperature $\left(>1100^{\circ} \mathrm{C}\right)$ to convert them [2]. The catalytic tar decomposition has been proposed to overcome these drawbacks. In addition, the use of a catalyst can enhance gas formation and modify the gaseous composition promoting the reforming reactions of hydrocarbons. Tar removal using a catalyst has been extensively studied. It is reported that nickel-based catalysts, alkaline metal oxides and alkaline earth metal oxides are suitable to reduce the amount of tar [3]. Alkali metal and alkaline earth metal are present in ash component of the biomass.

We focus on the tar reduction in a fluidized bed gasifier such as a fluidized bed and spouted bed system. Even though experiments on thermal decomposition and gasification of biomass in a fixed bed system have been widely studied, studies on heterogeneous reaction between tar and ash are yet to be studied [4]. Using an experimental system that assumes the heterogeneous reaction of ash and tar in a fluidized bed gasifier, to evaluate the catalytic effect of the ash is significance. In this study, we have conducted an experiment thermal decomposition of cellulose by constructing an experimental device that assumes the heterogeneous reaction in a fluidized bed gasifier. Cellulose is a major component of wood and plant biomass [5]. The thermal decomposition of cellulose experiment by introducing the ash, we have considered the effect of ash is given to the heterogeneous reaction with tar. We have calculated the yields of char from the results of the thermogravimetry-differential thermal analysis (TGDTA) experiment, have measured the yields of condensable products were 
cooled down and collected in the test tube, have measured the yields of gas by GC-TCD/FID.

\section{Materials and experimental methods}

\subsection{Matarials}

The tested experimental sample was the microcrystalline cellulose with an average diameter of $50 \mu \mathrm{m}$ (SERVA). The chemical formula for this sample polymer could be approximated as $\left(\mathrm{C}_{6} \mathrm{H}_{6} \mathrm{O}_{5}\right)_{n}$, confirming the linearly polymerized structure of the glucopyranose linked by $\beta$-1, 4-glycosidic bonds. The analysis of the cellulose had been performed using a CHN corder (Model MT-5, Yanaco Co. Ltd., Japan) for elemental analysis and proximate analysis were also performed. Cellulose composition is presented in table 1 .

Table 1: $\quad$ Elemental analysis and proximate analysis of cellulose.

\begin{tabular}{c|c|c|c|c|c|c|c}
\hline \multicolumn{3}{c|}{ Elemental analysis (wt.\%) } & \multicolumn{5}{c}{ Proximate analysis (wt.\%) } \\
\hline $\mathrm{C}$ & $\mathrm{H}$ & $\mathrm{N}$ & $\mathrm{O}$ & Moisture & Volatiles & Fixed carbon & Ash \\
\hline 43.31 & 6.23 & 0.00 & 50.46 & 7.18 & 86.90 & 5.92 & 0.00 \\
\hline
\end{tabular}

Potassium and calcium were alkali metal and alkaline earth metal species contained in the biomass. $\mathrm{K}_{2} \mathrm{CO}_{3}$ (Wako, assay min.99.5\%) and $\mathrm{Ca}(\mathrm{OH})_{2}$ (Wako, assay $\min .96 .0 \%$ ) were used in the study as ash model. Silicon dioxide (Wako) was used as a fluidizing medium [6].

\subsection{TG-DTA experiment}

The pyrolysis of cellulose was carried out in a TG-DTA (Model DTG-60, Shimadzu Co. Ltd., Japan), in order to calculate the yield of char and survey of pyrolysis behavior. The sample was weighed 5.00-7.00 $\mathrm{mg}$ and, placed on the scales in the apparatus. The sample was heated up to $900^{\circ} \mathrm{C}$ at a constant heating rate of $10^{\circ} \mathrm{C} / \mathrm{min}$. Argon at a flow rate of $70 \mathrm{ml} / \mathrm{min}$ was used as the carrier gas to provide an inert atmosphere for pyrolysis and to remove the gaseous and condensable products.

\subsection{Thermal decomposition of cellulose}

\subsubsection{The experimental apparatus for cellulose pyrolysis and gasification}

Figure 1 shows the scheme of the experimental setup used for cellulose pyrolysis and gasification. It was composed of gas feeding system, pyrolysis system, tar decomposition system, condensable products trapping system and, gaseous products measurement system. Pyrolysis system and tar decomposition system consisted of connecting the two stainless reactor (I.D.; $21.4 \mathrm{~mm}$, length; $500 \mathrm{~mm}$ ). Cellulose and $\mathrm{K}_{2} \mathrm{CO}_{3}, \mathrm{Ca}(\mathrm{OH})_{2}$, silicon dioxide were placed on the mesh $(40 \mu \mathrm{m})$ in the each reactor. This apparatus can be independently heated in two different electric furnaces while the gas mixture coming in contact with the 
catalyst. Therefore, heterogeneous reaction between tar and ash can be carried out by using the apparatus. The lines between the first and second reactor as well as between the second reactor and the condensable products trapping system were heated in between $300-400^{\circ} \mathrm{C}$ to avoid the condensation of tar. Condensable products were collected by cooling the test tube and the collection efficiency was improved by using glass beads. The Cooling bath was kept below $-3^{\circ} \mathrm{C}$ by mixing water, ice and sodium chloride. The Gaseous products were measured by a GC-TCD/FID (Model GC-2014, Shimadzu Co. Ltd., Japan). $\mathrm{H}_{2}$ and $\mathrm{CO}, \mathrm{CH}_{4}, \mathrm{CO}_{2}$ were measured by a GC-TCD while hydrocarbons $\left(\mathrm{C}_{2} \mathrm{H}_{6}\right.$ and $\mathrm{C}_{2} \mathrm{H}_{4}, \mathrm{C}_{3} \mathrm{H}_{8}, \mathrm{C}_{3} \mathrm{H}_{6}$, iso- $\mathrm{C}_{4} \mathrm{H}_{10}, \mathrm{n}-\mathrm{C}_{4} \mathrm{H}_{10}$ ) were measured by a GC-FID.

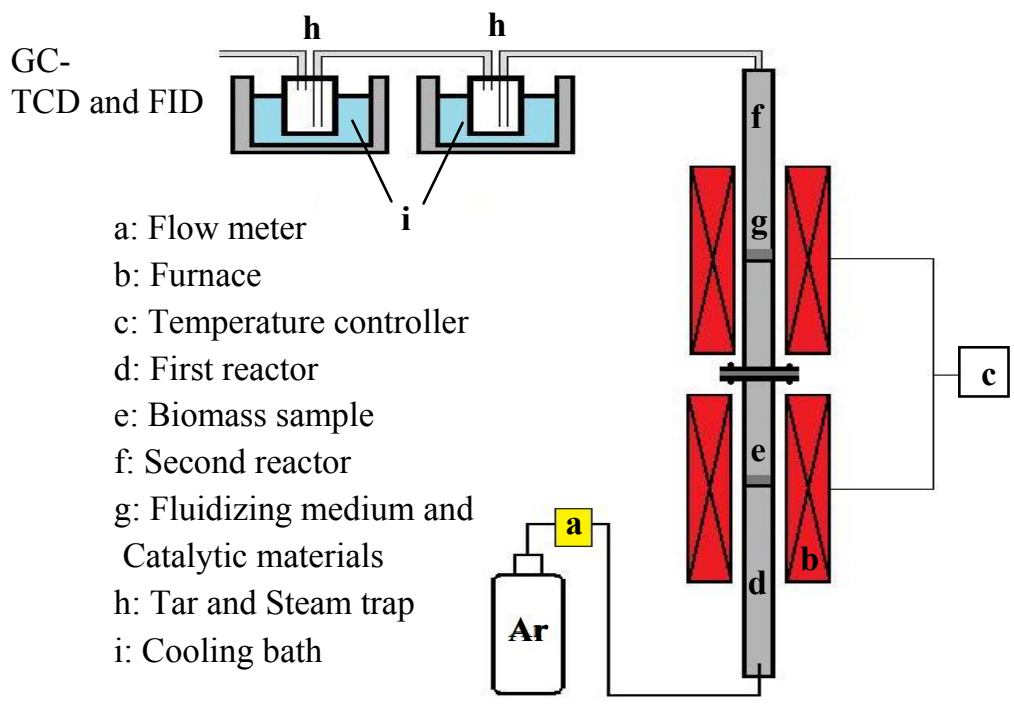

Figure 1: Experimental setup for cellulose pyrolysis and gasification.

\subsubsection{The experimental procedure}

The operative conditions are reported in table 2. Cellulose, catalysts, silicon dioxide were placed in each reactor under the condition of table 2, respectively. The Second reactor was heated up to a predetermined temperature under argon at constant flow rate. Then, first reactor was heated up $\left(\right.$ at $10^{\circ} \mathrm{C} / \mathrm{min}$ up to $\left.900^{\circ} \mathrm{C}\right)$ and the gaseous products were measured at every $80^{\circ} \mathrm{C}$ to $900^{\circ} \mathrm{C}$ from $180^{\circ} \mathrm{C}$ by a GC-TCD/FID.

\subsubsection{The yields of pyrolysis products}

The yields of char were calculated from TG-DTA analysis. The yields of condensable products were determined by the weight difference of the test tube before and after the experiment. The yield of gaseous products was calculated from the measurement results of GC-TCD/FID. Also, subtracting the amount of char, the amount of condensable products, and the amount of gaseous products 
Table 2: $\quad$ Operative conditions used for tests.

\begin{tabular}{|c|c|c|c|c|}
\hline Item & First reactor & \multicolumn{3}{|c|}{ Second reactor } \\
\hline & & none & $\mathrm{K}_{2} \mathrm{CO}_{3}$ & $\mathrm{Ca}(\mathrm{OH})_{2}$ \\
\hline Cellulose amount (g) & 2.00 & & - & \\
\hline Catalyst amount (g) & - & - & 0.691 & 0.741 \\
\hline Silicon dioxide amount $(\mathrm{g})$ & - & 5.00 & 4.309 & 4.259 \\
\hline Heating rate $\left({ }^{\circ} \mathrm{C} / \mathrm{min}\right)$ & 10 & & - & \\
\hline Maximum temperature $\left({ }^{\circ} \mathrm{C}\right)$ & 900 & $\begin{array}{l}500,700, \\
800,900\end{array}$ & 700,800 & 700,800 \\
\hline Argon flow rate $(\mathrm{ml} / \mathrm{min})$ & & 70 & & \\
\hline
\end{tabular}

from the amount of cellulose was evaluated as a heavy tar. The heavy tar is a tar which remains in the apparatus.

\section{Results and discussions}

\subsection{The results from TG-DTA analysis}

The pyrolysis characteristics, both TG (wt.\%) and DTA $(\mu \mathrm{V})$ curves of cellulose found out with a TG-DTA has shown in figure 2. Rapid weight loss of cellulose was observed between $300-400^{\circ} \mathrm{C}$, and then the weight loss had progressed slowly. Endothermic peak was observed between $300-400^{\circ} \mathrm{C}$, indicating that the thermal decomposition of cellulose was occurring in this temperature range [7]. Furthermore, the weight loss was also observed in the same temperature range. Thus, it should be predicted that a large amount of thermal decomposition products released in this temperature. A gradual weight loss was continued after

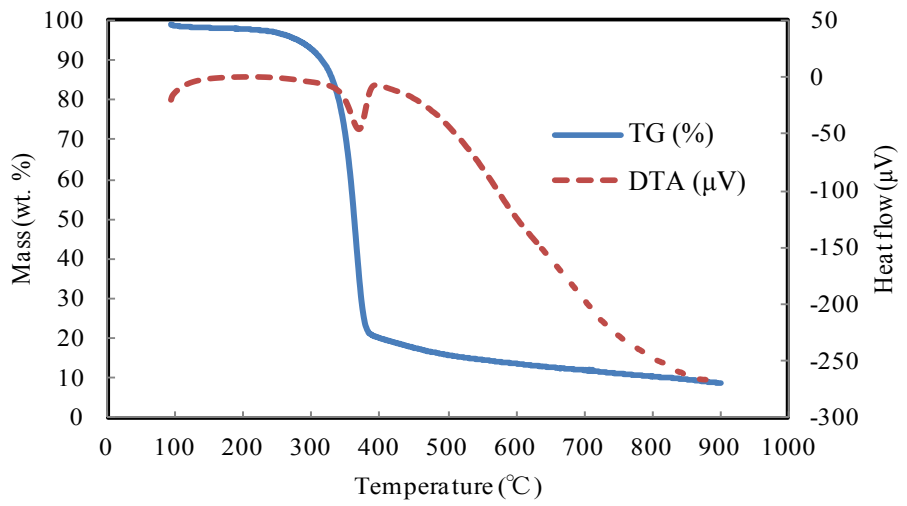

Figure 2: $\quad$ Pyrolysis curves of cellulose in the TG-DTA analysis. 
$400^{\circ} \mathrm{C}$, it should be predicted that a small amount of thermal decomposition products have been released. Experiments were carried out several times under the same conditions and, it was within $\pm 5 \%$ maximum error. Thus, in this study, char yields of cellulose pyrolysis were calculated to be $8.90 \%$ (wt.\%).

\subsection{Thermal decomposition of cellulose}

Figures 3-6 showed the molar quantity ( $\mathrm{mmol} / \mathrm{g}$-cellulose) of gaseous products generated by thermal decomposition of cellulose at each experimental condition. Also, table 3 showed the total molar quantity (mmol/g-cellulose) of gaseous products generated by thermal decomposition of cellulose at each experimental condition.

Table 3: Total molar quantity (mmol/g-cellulose) of gaseous products in each second reactor conditions.

\begin{tabular}{lccccc}
\hline \multicolumn{1}{c}{$\begin{array}{c}\text { Second reactor } \\
\text { conditions }\end{array}$} & $\mathrm{H}_{2}$ & $\mathrm{CO}$ & $\mathrm{CH}_{4}$ & $\mathrm{CO}_{2}$ & Hydrocarbons \\
\hline $500^{\circ} \mathrm{C}$ & 0.493 & 3.531 & 0.333 & 0.921 & 0.149 \\
$700^{\circ} \mathrm{C}$ & 1.892 & 5.059 & 1.114 & 1.225 & 0.979 \\
$700^{\circ} \mathrm{C}-\mathrm{K}_{2} \mathrm{CO}_{3}$ & 2.033 & 6.088 & 1.244 & 1.710 & 1.039 \\
$700^{\circ} \mathrm{C}-\mathrm{Ca}(\mathrm{OH})_{2}$ & 3.359 & 8.116 & 1.626 & 1.709 & 1.393 \\
$800^{\circ} \mathrm{C}$ & 3.638 & 6.411 & 1.454 & 1.847 & 1.112 \\
$800^{\circ} \mathrm{C}-\mathrm{K}_{2} \mathrm{CO}_{3}$ & 4.665 & 6.487 & 1.590 & 2.759 & 1.288 \\
$800^{\circ} \mathrm{C}-\mathrm{Ca}(\mathrm{OH})_{2}$ & 5.294 & 9.691 & 2.040 & 2.993 & 1.395 \\
$900^{\circ} \mathrm{C}$ & 5.751 & 8.673 & 1.847 & 2.268 & 1.146 \\
\hline
\end{tabular}

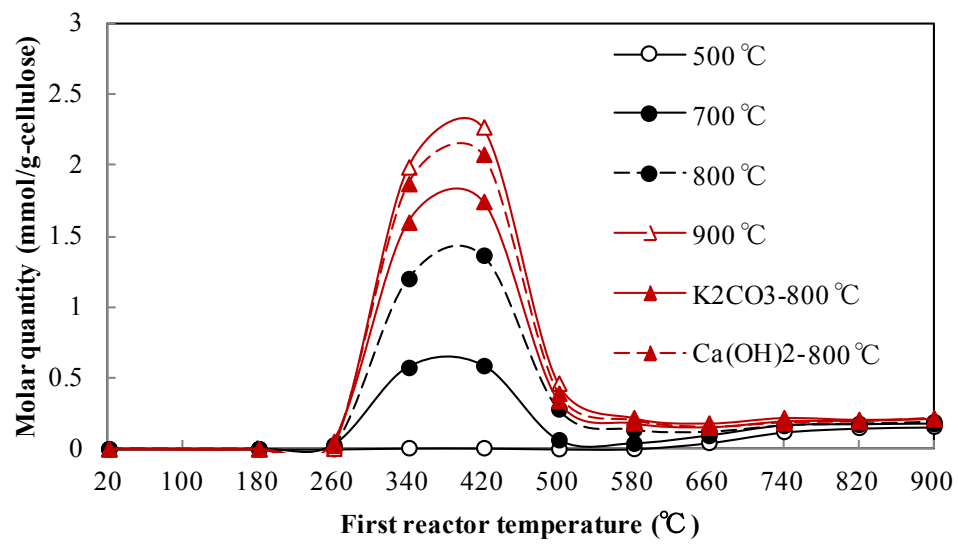

Figure 3: $\quad$ Molar quantity of $\mathrm{H}_{2}$ in each second reactor conditions. 


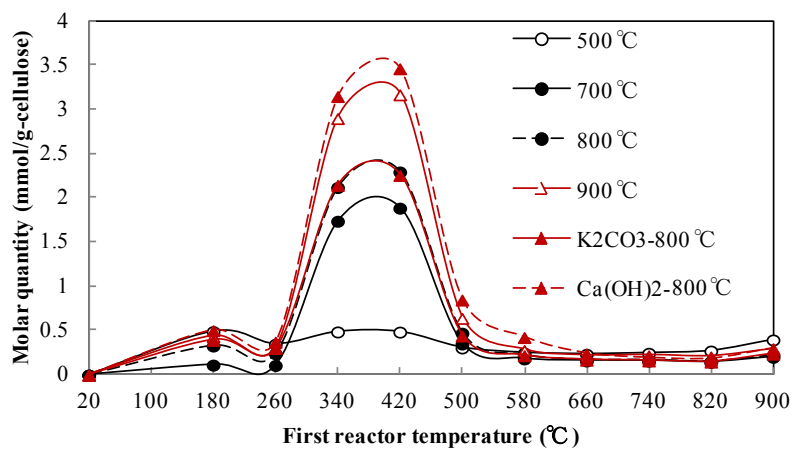

Figure 4: $\quad$ Molar quantity of $\mathrm{CO}$ in each second reactor conditions.

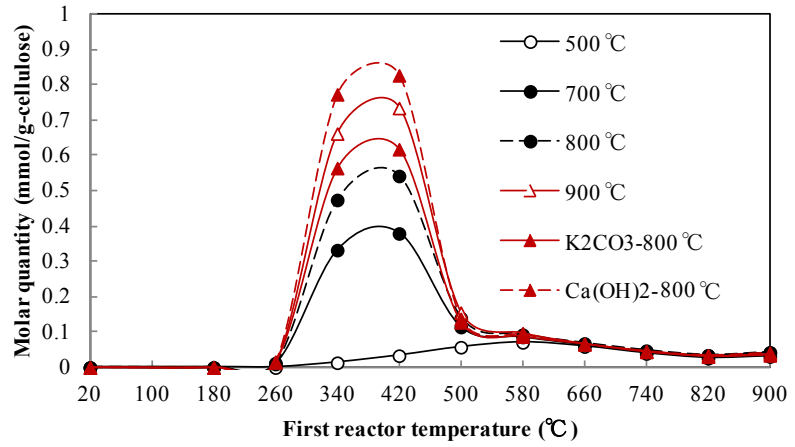

Figure 5: $\quad$ Molar quantity of $\mathrm{CH}_{4}$ in each second reactor conditions.

In the second reactor temperature at $900^{\circ} \mathrm{C}$, total molar quantity of $\mathrm{H}_{2}$ was maximum while it was minimum at the second reactor temperature at $500^{\circ} \mathrm{C}$. At the second reactor temperature at $500^{\circ} \mathrm{C}$, the generation of $\mathrm{H}_{2}$ began to increase rapidly after about $600^{\circ} \mathrm{C}$. However, $\mathrm{H}_{2}$ generation was remarkable in between $300-500^{\circ} \mathrm{C}$ under experimental conditions. The case of second reactor temperature at $500^{\circ} \mathrm{C}$, the generation of $\mathrm{H}_{2}$ was not observed only a small amount in that temperature range. The total molar quantity of $\mathrm{H}_{2}$ was increased as the second reactor temperature conditions rise. Total molar quantity of $\mathrm{H}_{2}$ was increased approximately $7.5 \%$ after adding $\mathrm{K}_{2} \mathrm{CO}_{3}$ compared to the molar quantity observed with the presence of only silicon dioxide at $700^{\circ} \mathrm{C}$. However, total molar quantity of $\mathrm{H}_{2}$ was increased nearly $77.6 \%$ after installing $\mathrm{Ca}(\mathrm{OH})_{2}$. Compared with the presence of only silicon dioxide in the second reactor at $800^{\circ} \mathrm{C}$, the total molar quantity of $\mathrm{H}_{2}$ was increased about $28.2 \%$ and $45.5 \%$ when presence $\mathrm{K}_{2} \mathrm{CO}_{3}$, and $\mathrm{Ca}(\mathrm{OH})_{2}$ respectively. 


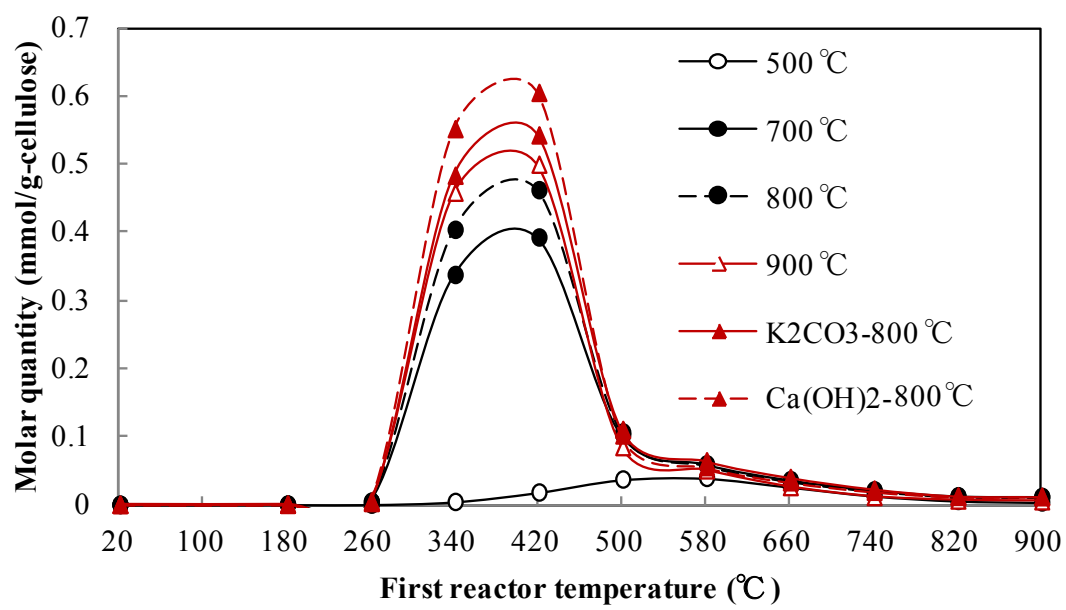

Figure 6: Molar quantity of hydrocarbons ${ }^{\mathrm{a}}$ in each second reactor conditions. ${ }^{a}$ Here, hydrocarbons are $\mathrm{C}_{2} \mathrm{H}_{6}$ and $\mathrm{C}_{2} \mathrm{H}_{4}, \mathrm{C}_{3} \mathrm{H}_{8}, \mathrm{C}_{3} \mathrm{H}_{6}$, iso- $\mathrm{C}_{4} \mathrm{H}_{10}$, $\mathrm{n}-\mathrm{C}_{4} \mathrm{H}_{10}$ in the study.

In the case of $\mathrm{Ca}(\mathrm{OH})_{2}$ was placed in second reactor at $800^{\circ} \mathrm{C}$, total molar quantity of $\mathrm{CO}$ was maximum while it was minimum, in the case of second reactor temperature at $500^{\circ} \mathrm{C}$. The generation of $\mathrm{CO}$ was remarkable between $300-500^{\circ} \mathrm{C}$ in all experimental conditions. Compared to the condition where only silicon dioxide was placed in the second reactor at $700^{\circ} \mathrm{C}$, the total molar quantity of $\mathrm{CO}$ was increased about $20.4 \%$ after adding $\mathrm{K}_{2} \mathrm{CO}_{3}$. However, it was further increased nearly $60.4 \%$ when $\mathrm{Ca}(\mathrm{OH})_{2}$ was installed. Quantity of $\mathrm{CO}$ was increased nearly $1.2 \%$ and $51.1 \%$ with the presence of $\mathrm{K}_{2} \mathrm{CO}_{3}$ and $\mathrm{Ca}(\mathrm{OH})_{2}$ respectively compared to the $\mathrm{CO}$ quantity observed at only silicon dioxide placed in the second reactor at $800^{\circ} \mathrm{C}$. The total molar quantity of $\mathrm{CO}$ when it was installed $\mathrm{Ca}(\mathrm{OH})_{2}$ without changing the second reactor temperature, was higher than when the second reactor temperature was raised to $700-800^{\circ} \mathrm{C}$ and 800 $900^{\circ} \mathrm{C}$. CO was most generated in the pyrolysis gaseous products.

In the case of $\mathrm{Ca}(\mathrm{OH})_{2}$ was placed in second reactor at $800^{\circ} \mathrm{C}$, total molar quantity of $\mathrm{CH}_{4}$ was maximum and it was minimum in the case of second reactor temperature at $500^{\circ} \mathrm{C}$. The generation of $\mathrm{CH}_{4}$ was remarkable between 400$800^{\circ} \mathrm{C}$ when the second reactor temperature at $500^{\circ} \mathrm{C}$ while it was remarkable in between $300-500^{\circ} \mathrm{C}$ under other experimental conditions. The case of second reactor temperature at $500^{\circ} \mathrm{C}$, the generation of $\mathrm{CH}_{4}$ was not observed only a small amount in that temperature range. As the second reactor temperature conditions to rise, the total molar quantity of $\mathrm{CH}_{4}$ was increased. Compared to the condition where only silicon dioxide was placed in the second reactor at $700^{\circ} \mathrm{C}$, the total molar quantity of $\mathrm{CH}_{4}$ was increased about $11.7 \%$ and $46.0 \%$ by adding $\mathrm{K}_{2} \mathrm{CO}_{3}$ and $\mathrm{Ca}(\mathrm{OH})_{2}$ respectively. Compared with when only silicon dioxide was placed in the second reactor at $800^{\circ} \mathrm{C}$, the total molar quantity of $\mathrm{CH}_{4}$ was increased about $9.4 \%$ by installing $\mathrm{K}_{2} \mathrm{CO}_{3}$, on the other hand, the total 
molar quantity of $\mathrm{CH}_{4}$ was increased about $40.4 \%$ by installing $\mathrm{Ca}(\mathrm{OH})_{2}$. The rate of the total molar quantity of $\mathrm{CH}_{4}$ when it was installed $\mathrm{Ca}(\mathrm{OH})_{2}$ without changing the second reactor temperature, was higher than when the second reactor temperature was raised to $700-800^{\circ} \mathrm{C}$ and $800-900^{\circ} \mathrm{C}$.

In the case of $\mathrm{Ca}(\mathrm{OH})_{2}$ was placed in second reactor at $800^{\circ} \mathrm{C}$, total molar quantity of $\mathrm{CO}_{2}$ was maximum, and it was minimum in the case of second reactor temperature at $500^{\circ} \mathrm{C}$. The generation of $\mathrm{CO}_{2}$ was remarkable between $300-500^{\circ} \mathrm{C}$ in all experimental conditions. As the second reactor temperature condition rise, the total molar quantity of $\mathrm{CO}_{2}$ was increased. Compared to the condition where only silicon dioxide was placed in the second reactor at $700^{\circ} \mathrm{C}$, the total molar quantity of $\mathrm{CO}_{2}$ was increased about $39.6 \%$ by installed $\mathrm{K}_{2} \mathrm{CO}_{3}$. However it was increased nearly $39.5 \%$ after installing $\mathrm{Ca}(\mathrm{OH})_{2}$. Compared with when only silicon dioxide was placed in the second reactor at $800^{\circ} \mathrm{C}$, the total molar quantity of $\mathrm{CO}_{2}$ was increased about $49.4 \%$ by installing $\mathrm{K}_{2} \mathrm{CO}_{3}$. However, the total molar quantity of $\mathrm{CO}_{2}$ was increased about $62.0 \%$ by $\mathrm{Ca}(\mathrm{OH})_{2}$. The amount of the total molar quantity of $\mathrm{CO}_{2}$ with the presence of $\mathrm{K}_{2} \mathrm{CO}_{3}$ and $\mathrm{Ca}(\mathrm{OH})_{2}$ without changing the second reactor temperature was higher than that of when the second reactor temperature was raised to 800$900^{\circ} \mathrm{C}$.

In the case of $\mathrm{Ca}(\mathrm{OH})_{2}$ was placed in second reactor at $800^{\circ} \mathrm{C}$, total molar quantity of hydrocarbons was maximum while minimum quantity of hydrocarbons was observed when second reactor temperature at $500^{\circ} \mathrm{C}$. The case of second reactor temperature at $500^{\circ} \mathrm{C}$, the generation of hydrocarbons was remarkable between about $400-800^{\circ} \mathrm{C}$. However, generation of hydrocarbons was remarkable between about $300-500^{\circ} \mathrm{C}$ at other experimental conditions, the. The case of second reactor temperature at $500^{\circ} \mathrm{C}$, the generation of hydrocarbons was not observed and only a small amount occurred in that temperature range. As the second reactor temperature conditions to rise, the total molar quantity of hydrocarbons was increased. Total molar quantity of hydrocarbons were increased approximately $6.1 \%$ and $42.2 \%$ by $\mathrm{K}_{2} \mathrm{CO}_{3}$ and $\mathrm{Ca}(\mathrm{OH})_{2}$ respectively compared to the total molar quantity of hydrocarbons when only silicon dioxide was placed in the second reactor at $700^{\circ} \mathrm{C}$. Compared with when only silicon dioxide was placed in the second reactor at $800^{\circ} \mathrm{C}$, the total molar quantity of hydrocarbons was increased about $15.8 \%$ after installing $\mathrm{K}_{2} \mathrm{CO}_{3}$ while it was increased about $25.4 \%$ after installing $\mathrm{Ca}(\mathrm{OH})_{2}$. The quantity of the total molar quantity of hydrocarbons when it was installed $\mathrm{Ca}(\mathrm{OH})_{2}$ without changing the second reactor temperature, was higher than that of the second reactor temperature raised to $800-900^{\circ} \mathrm{C}$.

Total molar quantity of all gas species were increased with the increase of the second reactor temperature, its cause should be a secondary pyrolysis reaction of cellulose pyrolysis products in second reactor. At higher second reactor temperature, heavier tar could be pyrolyzed, thus, the generation of additional gas and carbon constituent is expected. Differences in temperature conditions generated, a large amount of gas from secondary pyrolysis and gasification of tar than primary pyrolysis. That could be the reason for the significant difference in the total molar quantity of gas production [8]. In the case of second reactor 
temperature conditions are same, total molar quantity of all gas species increased after installing $\mathrm{K}_{2} \mathrm{CO}_{3}$ and $\mathrm{Ca}(\mathrm{OH})_{2}$. Also, under certain experimental conditions, there should be an increase in the total molar quantity of gaseous products rather than rising temperature when, the catalyst was installed. On the basis of these results, it can be concluded that addition of $\mathrm{K}_{2} \mathrm{CO}_{3}$ and $\mathrm{Ca}(\mathrm{OH})_{2}$ significantly increased gas production. Compared to $\mathrm{Ca}(\mathrm{OH})_{2}$, relatively higher amount of gas is produced in the presence of $\mathrm{K}_{2} \mathrm{CO}_{3}$. But the role of $\mathrm{K}_{2} \mathrm{CO}_{3}$ might have been underestimated. Because, $\mathrm{K}_{2} \mathrm{CO}_{3}$ reacts with silicon dioxide to form glass at temperature around $800^{\circ} \mathrm{C}$ [9]. Furthermore, the weight ratio of $\mathrm{K}_{2} \mathrm{CO}_{3}$ and silicon dioxide in the glass is somewhat similar to this study and the literature [10]. The melting temperature of $\mathrm{K}_{2} \mathrm{CO}_{3}$ is around $900^{\circ} \mathrm{C}$, thus, in this study, $\mathrm{K}_{2} \mathrm{CO}_{3}$ is not decomposed into $\mathrm{K}_{2} \mathrm{O}$ and $\mathrm{CO}_{2}[11]$.

In the case of second reactor temperature at $500^{\circ} \mathrm{C}$, the generation behavior of gas was very different from other temperature conditions and the molar quantity was also less. On the basis of these reasons, it can be estimated that secondary pyrolysis and gasification of tar was not much occurred. However, in other experimental conditions, it seems that a large amount of pyrolysis products between $300-400^{\circ} \mathrm{C}$ have been secondary pyrolyzed, and have contributed to the active gas generation between $300-500^{\circ} \mathrm{C}$.

Figure 7 showed comparison of mass balance on pyrolysis of cellulose. At the second reactor temperature at $500^{\circ} \mathrm{C}$, the largest fragment was condensable products while heavy tar represents the largest fraction at $700^{\circ} \mathrm{C}$. On the other hand, the fewest amounts of condensable products and heavy tar and total tar were found when $\mathrm{Ca}(\mathrm{OH})_{2}$ was placed in second reactor at $800^{\circ} \mathrm{C}$. The amount of condensable products and total tar were decreased, as the second reactor temperature rises. It could be due to the secondary pyrolysis reaction of cellulose pyrolysis products in second reactor. But the amount of heavy tar the case of second reactor temperature at $500^{\circ} \mathrm{C}$ was less than that of second reactor temperature at 700 and $800^{\circ} \mathrm{C}$. It is guessed that tar composition has been gradually changed heavier ones by proceeding pyrolysis at a high temperature, but this reaction might insufficient at $500^{\circ} \mathrm{C}$. In the case of second reactor temperature at $700^{\circ} \mathrm{C}$, the amount of condensable products and heavy tar and total tar were decreased by installing $\mathrm{K}_{2} \mathrm{CO}_{3}$ and $\mathrm{Ca}(\mathrm{OH})_{2}$. This result was the same at the $800^{\circ} \mathrm{C}$. On the basis of current findings, it can be concluded that $\mathrm{K}_{2} \mathrm{CO}_{3}$ and $\mathrm{Ca}(\mathrm{OH})_{2}$ effect on tar decomposition. Comparing the catalytic effect, $\mathrm{Ca}(\mathrm{OH})_{2}$ was superior to $\mathrm{K}_{2} \mathrm{CO}_{3}$. A comparison of the effect of tar decomposition when it was installed $\mathrm{Ca}(\mathrm{OH})_{2}$ without changing the second reactor temperature, which was higher than the second reactor temperature was raised to $700-800^{\circ} \mathrm{C}$. This result was also observed when the second reactor temperature was raised to $800-900^{\circ} \mathrm{C}$. This result can be considered as the effect of $\mathrm{Ca}(\mathrm{OH})_{2}$. In this study, $\mathrm{Ca}(\mathrm{OH})_{2}$ exists in a state of $\mathrm{CaO}$, such as high temperature, tar and secondary product char adhere to its surface [12]. Adhering material reacts with the pyrolysis product gas, the gas is further produced. Additionally, the polarity of the active site of $\mathrm{CaO}$ can affect the $\pi$-electron cloud's stability of condensed aromatic compounds, and $\mathrm{CaO}$ itself has a cracking active site on both inner and outer surfaces [13]. 


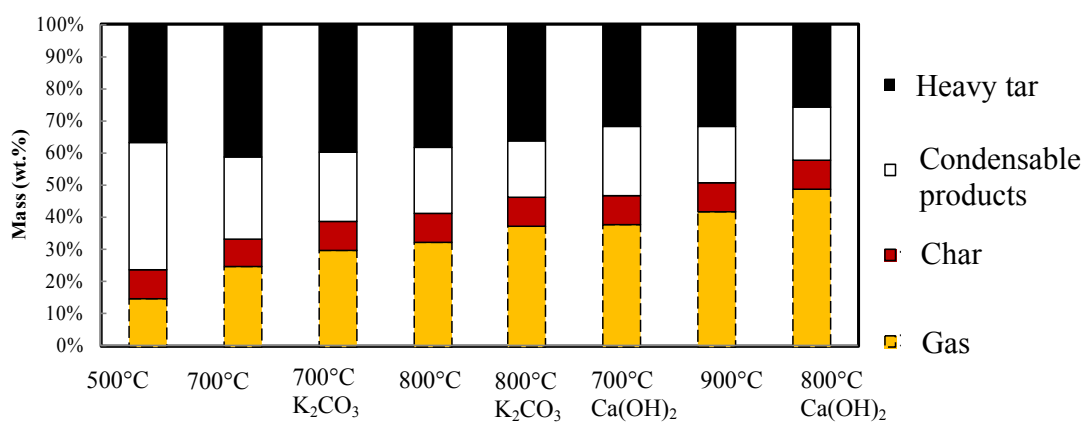

Figure 7: Comparison of mass balance on pyrolysis of cellulose.

\section{Conclusions}

In this study, the experimental apparatus connecting the two reaction tubes has been used for the study of heterogeneous reaction between tar and ash from cellulose pyrolysis and gasification modeling a fluidized bed gasifier. Alkali metal $\mathrm{K}$ and alkaline earth metal $\mathrm{Ca}$ were selected as the main ash contents that may act as the catalyst for tar decomposition. As the catalytic effect of alkali metal $\mathrm{K}$ and alkaline earth metal $\mathrm{Ca}$, they can not only change in the composition of the tar, but also reduce the condensable organic compounds. Additionally, $\mathrm{K}$ and $\mathrm{Ca}$ increase the amount of gaseous products. The catalytic effect of $\mathrm{Ca}(\mathrm{OH})_{2}$ was comparatively superior to $\mathrm{K}_{2} \mathrm{CO}_{3}$. However, the role of $\mathrm{K}_{2} \mathrm{CO}_{3}$ might have been underestimated. Because $\mathrm{K}_{2} \mathrm{CO}_{3}$ reacts with silicon dioxide to form glass at temperature around $800^{\circ} \mathrm{C}$. Based on the results of the present study, it can be concluded that $\mathrm{K}_{2} \mathrm{CO}_{3}$ and $\mathrm{Ca}(\mathrm{OH})_{2}$ have the catalytic effect to decompose the tar, to enhance gaseous production. In the case of using ash as a catalyst, it is necessary to take into account that it is also included the chlorides in the biomass to give the change in the thermal decomposition properties in the further study.

\section{Acknowledgement}

Some parts of this study were supported by the special funds for Basic Research (B) (No. 22404022, FY2010-2012) of Grant-in-Aid for Scientific Research of the Japanese Ministry of Education, Culture, Sports, Science and Technology (MEXT), Japan.

\section{References}

[1] S. Lin, World gasification process development for syngas production. Journal of the Japan Institute of Energy, 91, pp. 826-834, 2012. 
[2] R. Zhang, R. C. Brown, A. Suby and K. Cummer, Catalytic destruction of tar in biomass derived producer gas. Energy Conversion and Management, 45, pp. 995-1014, 2004.

[3] J. Han and H. Kim, The reduction and control technology of tar during biomass gasification/pyrolysis: An overview. Renewable and Sustainable Energy Reviews, 12, pp. 397-416, 2008.

[4] J. Hayashi, M. Iwatsuki, K. Morishita, A. Tsutsumi, C. Li and T. Chiba, Roles of inherent metallic species in secondary reactions of tar and char during rapid pyrolysis of brown coals in a drop-tube reactor. Fuel, 81, pp. 1977-1987, 2002.

[5] D.K. Shen and S. Gu, The mechanism for thermal decomposition of cellulose and its main products. Bioresource Technology, 100, pp. 64966504, 2009.

[6] A. Gomez-Barea and B. Leckner, Modeling of biomass gasification in fluidized bed. Progress in Energy and Combustion Science, 36, pp. 444509, 2010.

[7] H. Yang, R. Yan, H. Chen, D. H. Lee and C. Zheng, Characteristics of hemicelluloses, cellulose and lignin pyrolysis. Fuel, 86, pp. 1781-1788, 2007.

[8] T. Hosoya, H. Kawamoto and S. Saka, Pyrolysis gasification reactivities of primary tar and char fractions from cellulose and lignin as studied with a closed ampoule reactor. Journal of Analytical and Applied Pyrolysis, 83, pp. 71-77, 2008.

[9] E. M. Levin, C. R. Robbins and H. F. Mcmurdie, Phase Diagrams for Ceramists, Volume I: Oxides and Salts, American Ceramic Society, 1986.

[10] E. L. Bourhis, Glass, John Wiley and Sons, 2008.

[11] R. L. Lehman, J. S. Gentry and N. G. Glumac, Thermal stability of potassium carbonate near its melting point. Thermochimica Acta, 316, pp. 1-9, 1998.

[12] M. Widyawati, T. L. Church, N. H. Florin and A. T. Harris, Hydrogen synthesis from biomass pyrolysis with in situ carbon dioxide capture using calcium oxide. International Journal of Hydrogen Energy, 36, pp. 48004813, 2011.

[13] Z. Tingyu, Z. Shouyu, H. Jiejie and W. Yang, Effect of calcium oxide on pyrolysis of coal in a fluidized bed. Fuel Processing Technology, 64, pp. 271-284, 2000. 